\title{
当科に抢ける non-Hodgkin 悪性リンパ腫の臨床統計
}

$\begin{array}{llll}\text { 鶴田 } & \text { 至宏・田中 } & \text { 治・宮原 } & \text { 裕 } \\ \text { 兵 } & \text { 行和・松永 } & \text { 喬 }\end{array}$

\section{Review of Non-Hodgkin Lymphomas}

\author{
Yoshihiro Tsuruta, Osamu Tanaka, Hiroshi Miyahara, \\ Yukikazu Hyo and Takashi Matsunaga \\ (Nara Medical University)
}

The clinical, histological and prognostic features of 36 patients with non-Hodgkin lymphomas treated in the Nara Medical University hospital between January, 1982 and June, 1988 were reviewed.

Twenty one patients were male and 15 were female. The age range was from 11 to 79 years of age and had a peak in the seventies. In our clinic, elderly patients were dominant and could not be treated by intensive chemotherapy. According to the stage distribution for Ann Arbor classification, 12 cases were stage I, 15 were stage II, 6 were stage III and 2 were stage IV. Stage I and stage II accounted for $75 \%$. Five-year survival showed $92 \%$ in stage I, $47 \%$ in stage II, $0 \%$ in stage III and IV and $52 \%$ in all cases. By site grouping, 21 cases were Waldeyer's ring, 7 were nodal and 8 were extranodal except for Waldeyer's ring. Waldeyer's ring was the most common site of extranodal lymphomas, these tumors adopting more favorable courses. Histologically, these cases were categorized according to the working formulation. Three cases were low grade, 26 were intermediate grade and 3 were high grade. The 5 -year survival rate was $67 \%$ with low grade, $55 \%$ with intermediate grade and $0 \%$ with high grade.

Key words: non-Hodgkin lymphoma, malignant lymphoma, clinical statistical study

\section{はじめに}

頭頸部初発 non-Hodgkin 悪性リンパ腫は, 放射線による優れた局所制御にもかかわらず, 遠隔部位に再然する症例を見ることがあり，近 年では I 期, II期のような早期例に対しても化 学療法を併用する趨勢にある. しかし化学療法 施行例の長期生存例では，不妊や二次発癌の問 題も示唆されており 1)2), 不必要な過剩治療は 避けなければならない，そこで今回われわれは
当科での治療成績を臨床的に検討し，治療の問 題点と，とくに予後を左右する病理組織学的な 因子について検討した。

\section{対象および治療法}

1982年 1 月から1988年 6 月までの 6 年 6 ケ月 の間に当科で加療を行った，頭頸部初発 nonHodgkin 悪性リンパ腫新鮮例36例を対象とし た。病期は初回治療開始時の病巣の広がりによ り, Ann Arbor 分類 ${ }^{3)}$ に従って決定した。全例 
試験開腹は行われず，すべて臨床病期である. 病期決定のために施行した検査は ${ }^{69} \mathrm{Ga}$ シンチ, 骨シンチ，腹部超音波検査，上部消化管造影， 骨髄穿刺，CT 検査であった。病理組織分類は Working Formulation 分類に従って行った．治 療法は I 期症例にはコバルト放射線治療単独で 40〜50 Gy を，また1984年以降では照射後に単 剂（主に cyclophosphamide）もしくは多剂 （CAP，VEMP 療法など）による化学療法を施 行した例もあった。 II 期症例には放射線治療 40〜50 Gy 先行で多剂併用の化学療法を加えた. III， N 期症例では主として多剤併用による化学 療法が施行され，放射線は局所的に併用された。

\section{結果}

1. 部位別発生頻度

頸部リンパ節初発が 7 例, Waldeyer 輪初発 が21例 (口蓋扁桃13例, 上咽頭 5 例, 舌根 3 例), 頸部リンパ節外初発が 8 例（鼻副鼻腔 5 例，甲 状腺 2 例，耳下腺 1 例）であった。性別では男 性21例，女性15例であった．年齢分布は11歳か ら79歳に扣よび，性別年齢分布は図 1 に示した

表 1 non-Hodgkin 悪性リンパ腫の初発部位別 の病期分類

\begin{tabular}{lcccc}
\hline \hline & Stage I & II & III & IV \\
\hline 頸部リンパ節初発 & 3 例 & & 3 & 1 \\
Waldeyer 輪初発 & 5 & 13 & 3 & \\
Waldeyer 輪以外の節外初発 & 4 & 2 & & 1
\end{tabular}

ごとく50歳以上の発症が多く, 発症のピークは 男女共に70歳代であった。年齢中央值は男性 59 歳，女性72歳で，全体では62歳であった.

2. 病期分類

病期分類は35例に可能であり， I 期 12 例， II 期15例， III 期 6 例， $\mathbb{N}$ 期 2 例であった.

病期分類と初発部位の関係は表 1 に示したご とくで, 頸部リンパ節初発では III, $\mathbb{N}$ 期が，そ れ以外では比較的早期例の占める割合が多かっ た。

病期分類と年齢分布の関係は表 2 に示したご とくで，早期例はいずれの年齢層にも発症して いたが， III期では 6 例中 5 例が 70 歳代に発症し ていた。

3. 病理組織学的分類

retrospective に検討可能な32例について病 理組織学的分類を行った (表 3 ). low grade 3 例, intermediate grade 26例, high grade 3 例であり, intermediate grade が $81 \%$ 占めた。

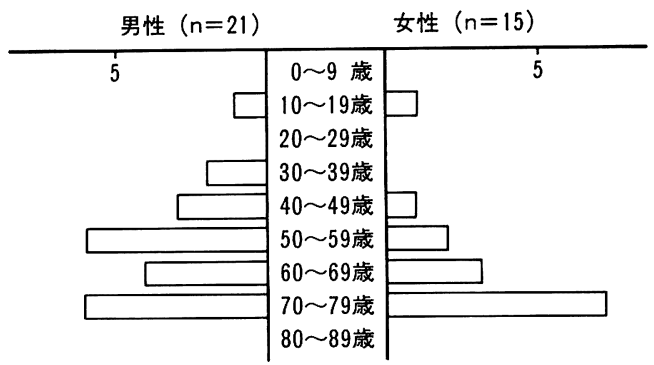

図 1 non-Hodgkin 悪性リンパ腫の性別年齢分布

表 2 non-Hodgkin 悪性リンパ腫の年齢別の病期分裂扰よび粗生存率

\begin{tabular}{|c|c|c|c|c|c|c|}
\hline & 例数 & Stage I & II & III & IV & 粗生存率 \\
\hline $0 \sim 9$ 歳 & & & & & & \\
\hline $10 \sim 19$ 歳 & 2 & & 2 & & & $100 \%$ \\
\hline $20 \sim 29$ 歳 & & & & & & \\
\hline $30 \sim 39$ 歳 & 2 & 2 & & & & $100 \%$ \\
\hline $40 \sim 49$ 歳 & 4 & 1 & 3 & & & $75 \%$ \\
\hline $50 \sim 59$ 歳 & 8 & 1 & 4 & 1 & 2 & $25 \%$ \\
\hline $60 \sim 69$ 歳 & 7 & 3 & 4 & & & $57 \%$ \\
\hline $70 \sim 79$ 歳 & 12 & 5 & 2 & 5 & & $50 \%$ \\
\hline $80 \sim 89$ 歳 & & & & & & \\
\hline
\end{tabular}


またこれらの内, M. L. diffuse mixed small and large cell 9 例, M. L. diffuse large cell 15 例と, この 2 type で大部分を占めていた. 32 例の内, follicular type は 1 例にすぎなかった。

\section{4. 治療成績}

図 2 に Kaplan Meier 法による治療症例の病 期別 5 年生存率を示した。 I 期では $92 \%$ ，II 期 では $47 \%, \mathbb{I I}, \mathbb{N}$ 期では 1 年以上の生存者はい なかった. I 期と II 期， II 期と II ・ I 期それぞ れの間に $1 \%$ 以下の危険率で有意差が認められ た. 病期は病勢の広がりを示すため, 当然予後 と密接な関係であった。 全体の 5 年生存率は 52 \%であった。

図 3 亿初発部位別の生存率を示した。各初発 部位にも予後の差が認められており, Waldeyer
輪初発では $65 \%$, 節外発症例・頸部リンパ節初 発では $42 \%$ と, Waldeyer 輪初発例では予後は 良好であった。

図 4 亿病理組織分類別の生存率を示した. low, intermediate, high grade と組織悪性度の 順に予後は不良となっていたが，例数に極端な 差があるため有意差は認められなかった。

図 5 に男女別の生存率を示した。男性では女 性に比べて予後は不良であったが，有意差は認 めなかった。

年齢別の粗生存率を表 2 に示したが，われわ れの施設では 50 歳代の治療成績が $25 \%$ ともっと も不良であり， 70 歳代は $50 \%$ の 5 年粗生存率で あった。

表 3 non-Hodgkin 悪性リンパ腫の病理組織分類

(Working Formulation 分類)

\begin{tabular}{l|lr}
\hline \hline \multirow{3}{*}{ Low Grade } & A. ML, small lymphocytic SL & 2 2例 \\
& B. ML, foll. small cleaved FSC & 1例 \\
& C. ML, foll. mixed FM & \\
\hline \multirow{4}{*}{ Intermediate Grade } & D. ML, foll. large cell FL & \\
& E. ML, diff. small cleaved DSC & 2 例 \\
& F. ML, diff. mixed DM & 9 例 \\
& G. ML, diff. large cell DL & 15 例 \\
\hline \multirow{3}{*}{ High Grade } & H. ML, large cell, immunoblastic IBL & 2 2例 \\
& I. ML, lymphoblastic LBL & 1 1例 \\
& J. ML, small non-cleaved SNC &
\end{tabular}

不明 4 例

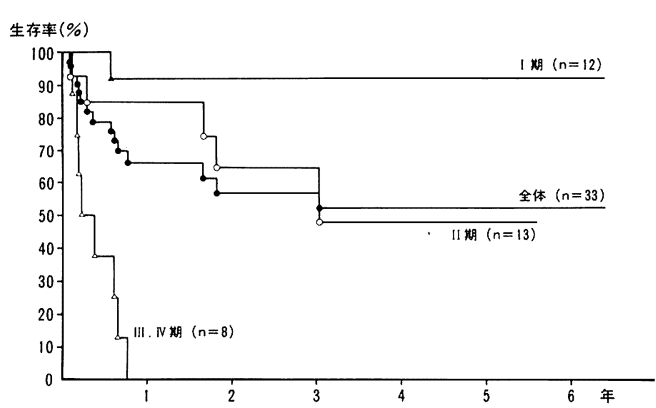

図 2 non-Hodgkin 悪性リンパ腫の病期別 生存率曲線

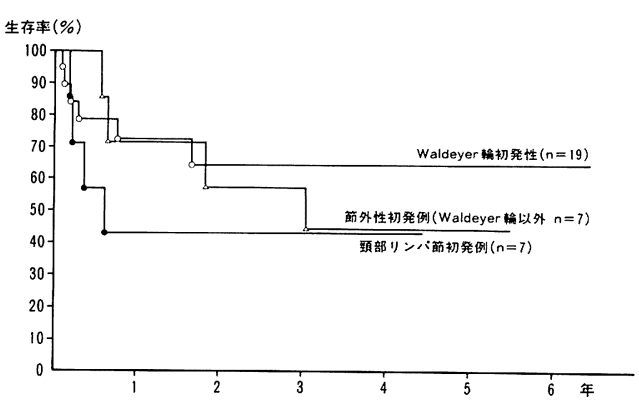

図 3 non-Hodgkin 悪性リンパ腫の初発部位別 生存率曲線 


\section{考察}

Non-Hodgkin 悪性リンパ腫については多数 の研究成果が報告されているのにもかかわらず, 未だに病期分類について普遍的なものがなく, UICC の TNM 分類) にも記載されていない. これは同じ悪性リンパ腫とされる Hodgkin 病 が腫瘍の発生部位や自然史が明らかにされてい るのに対し, non-Hodgkin 悪性リンパ腫では リンパ節だけでなく多種の臓器に発生し, その 自然史も人種や組織型で变わってくるからであ $ろ^{5)}$. この上らな本症を一括して扱らのは，あ たかも腺癌を病理組織の亜分類や発生部位を問 わずに分類しようとしているのに等しい. 残念 ながら本症の発生頻度は一施設で予後を検討で きる程ではなく，部位別の病期検討に至っては 不可能である。そこで現状では Hodgkin 病の Ann Arbor 分類に従って病期分類を行い, 腫 瘍の進展や予後と関連性の高い病理組織分類の 確立が望まれている．われわれの経験した症例 は少数ではあるが今回こうした考えに基づいて 治療症例の検討を試みた。

われわれの施設での年齢分布は70歳代に発症 のピークを示し，過去の6) 10) と比べても高齢 傾向が認められた．しかし性比は男性に多く, 発症部位別の頻度でも従来の報告と大差はなか っだ ${ }^{6)}$.

病期分類では I， II 期の早期例が 27 例 $(77 \%)$ と多かった。治療成績では 5 年生存率で I 期 92 $\%$ ， II 期47\%であるものの， III， $\mathrm{N}$ 期では $0 \%$

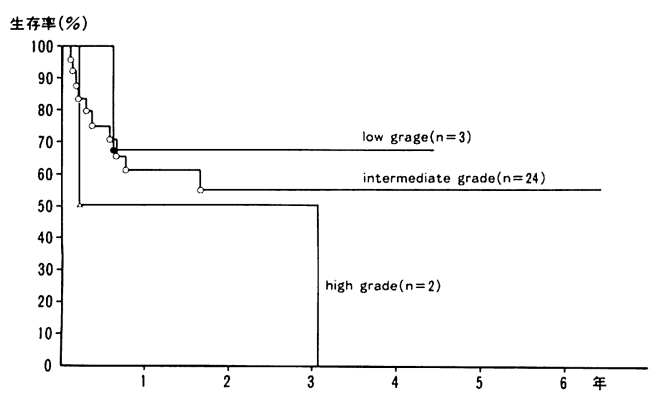

図 4 non-Hodgkin 悪性リンパ腫の組織悪性度 別生存率曲線
で 1 年生存例もなく, 放射線治療による局所制 御可能な頭頸部限局型以外では生存率は不良で あった．化学療法はIII期症例から併用されてい たものの，いずれも単剤やVEMP, COP 療法 などのアドリアマイシンを含まない多剤併用で あり，検討の余地があった。1986年以降ではア ドリアマイシンを含むVEPA 療法, さらに強 力な CHOP 療法を行っており, III 期以上の症 例でも寛解導入に到達することを目指している. また Klimo ら ${ }^{11)}$ の報告している MACOP-B な どの第三世代と言われる化学療法についても今 後検討していきたい。

年齢別にみるともっとも発症の多かった70歳 代の 12 例中の III 期症例が 5 例と $42 \%$ を占めて拉 り,この年代での病期の進行が, 強力な治療を 困難にしていた。高齢者では合併症のある場合 も多く，骨䯣抑制などの副作用も強く現れる. そのため適宜, 薬剤の減量, 投与回数の減数を 行っていた。この点については年齢はあまり関 係なくむしろ個人差が大きく, 減量は必ずしも 必要でないとの報告もある12)。また薬剤量の減 量は治療効果を低下させるとの報告13)14) もあり, 全身管理を向上させることで対応していく必要 がある。

従来報告されているよらに, 初発部位でも予 後の差が認められ, Waldeyer 輪初発では予後 良好で, 頸部リンパ節初発では予後不良であっ た8115)。われわれの症例では頸部リンパ節初発 例は, Waldeyer 輪初発例に比べて比較的病期

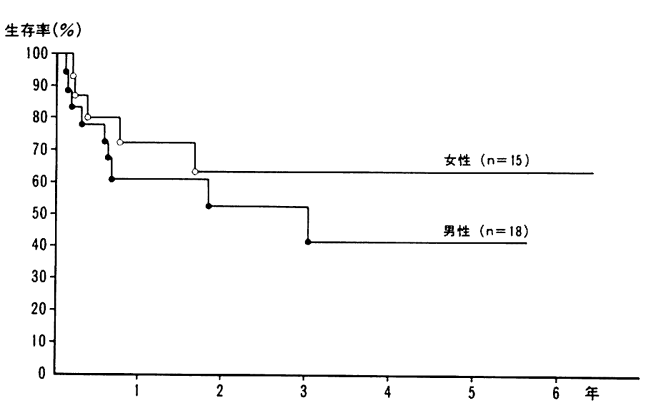

図 5 non-Hodgkin 悪性リンパ腫の性別生存率 曲線 
の進行した例が多く，これが予後を左右してい た。尾山 ${ }^{15)}$ の報告によると, 部位別の予後の 差は病理組織学的な差によると述べていたが， われわれの症例では high grade に分類された 症例が少数であり予後の差をもたらしたとは判 定できなかった。

病理組織学的分類には今回 Working Formulation 分類を用いた.これはBリンパ腫を 中心に考案された国際分類であり，ATL に代 表される Tリンパ腫が多く発症する本邦では LSG 分類 ${ }^{16)}$ の方が妥当性があるとも言われて いる. 近年の免疫組織学的検查により ATL 以 外のTリンパ腫の発生が意外にも多いことが判 明して扮り 17$)$, LSG 分類に配慮されたATLを 意識した diffuse lymphoma, pleomorphic type はTリンパ腫の大部分を包括し得ているわけで はなく，予後とより相関性があるとされている Working Formulation 分類を選んだ. 36例を再 検討し亜分類の確定できた32例について見てみ ると intermediate grade が $81 \%$ と大多数を占め, non-Hodgkin 悪性リンパ腫の内からごく少数 の比較的予後の良い low grade ときわめて予後 の不良な high grade が判定されたに過ぎず, 過去の報告18) の上らに予後の上でな扮差のあ ると思われる種々のリンパ腫が混在したまま, 大半の例が intermediate grade として扱われて いる.

high grade の症例については 3 年を越えて生 存した症例がなく，たとえ早期例であっても初 回治療時から強力な化学療法の併用が望まれ, 過去の報告19) のよらに, high grade の症例で は病期を 1 ランク上げて取り扱ら方がよいと思 われる. 一方, intermediate grade では M. L. diffuse mixed 9 例, M. L. diffuse large cell 15 例とこの 2 type で全体の75\%を占めていた. これらでは同じく large cell を含む high grade の M. L. large cell, immunoblastic との鑑別が 困難な症例が認められ，この鑑別は予後に差を もたらすため重要と思われた。

近年, モノクローナル抗体による表面マー
カーの検索により T, B リンパ腫の検討がなさ れ，とくに $\mathrm{T}$ ンパ腫は予後不良の病理組織学 的特徵として診断や治療法の選択に欠かせない ものになってきている6)17)18). われわれの施設 ではホルマリン固定後のパラフィン標本による 検討を行ったが，残念ながら viability の高い データではなく, 信頼性に乏しく今回は公表し なかった．今後ぜひ検討して行きたい問題点で ある。

$$
\text { まとめ }
$$

1982年 1 月から1988年 6 月までの間に当科を 受診した新鮮 non-Hodgkin 悪性リンパ腫36例 を検討し以下の結果を得た。

1. 年齢中央值は62歳で, 70 歳代に発症の ピーク（12例，42\%）があり, 強力な化学療法 を困難にしていた。

2. 予後をもっとも反映していたのは病期分 類であり， I 期 $92 \% ，$ II 期 $47 \% ，$ III ・ N 期には 生存者はいなかった。

3. Working Formulation 分類による病理組 織学的検討では low grade 3 例, intermediate grade 26例, high grade 3 例であり, 各々の予 後は $67 \% ， 55 \% ， 0 \%$ あった。たとえ早期例 でも予後のきわめて不良な high grade では1 ランク病期を上げて取り扱うべきである.

4. 病理組織の亜分類では diffuse mixed と diffuse large cell で24例を占めたが，これら 2 type と large cell, immunoblastic との鑑別が困 難な症例が認められた。

本論文の要旨は第226，227回日本耳鼻咽喉科学会 大阪地方連合会および第90回日本耳鼻咽喉科学会総 会（大阪）において講演した.なお今回病理標本を再 検討するに当りご協力をいただいた奈良県立医科大 学第一病理学教室, 安達博成氏に謝意を表します。

\section{文献}

1) Redman J, Bajorunas D, Goldstein M, et al : Semen cryoreservation and artificial insemination in Hodgkin's disease. Proc Am Soc Clin Oncol $2: 219,1983$.

2) Vaughan W, Karp J and Burke P : Effective 
chemotherapy of acute myelocytic leukemia occurring after alkylating agent of radiation therapy for prior malignancy. J Clin Oncol 1 : 204 207, 1983.

3) Lukes RJ, Craver LF, Hall TC, et al : Report of the nomenclature committiee. Cancer Res $26: 1311,1966$.

4) UICC : TNM Classification of Malignant Tumors, Fourth edition. 175 180, 1987.

5) 渡辺 昌, 大野優子: 覀性リンパ腫の疫学. 癌 の臨床 $34: 517 \sim 527,1988$.

6）手島昭樹, 茶谷正史, 井上俊彦, 他: 頭頸部初 発の Non-Hodgkin 悪性リンパ腫の検討. 癌の 臨床 $31: 363 \sim 369,1985$.

7）小川晃広, 宇野欽哉, 小池聰之, 他: 非ホジキ ンリンパ腫の臨床的検討一ワルダイエル輪原発 症例を中心にして一. 日耳鼻 $90: 723 \sim 729$, 1987.

8）早㴊尚文：Non-Hodgkin リンパ腫の研究一病 理組織学的分類と占拠部位を中心として一. 日 本医放会誌 $40 ： 1153 \sim 1167,1980$.

9）鈴木賢二, 馬場駿吉, 島田純一郎, 他 : 頭頸部 ホジキンリンパ腫に対する併用療法. 癌と化学 療法 $12: 3261 \sim 3265,1988$.

10）堀内淳一, 橴谷均, 新部英男, 他: 頭頸部》 ンパ節外性非ホジキンリンパ腫の放射線治療成 績. 癌の臨床 $33:$ 762 768, 1987.

11) Klimo $P$ and Connors JM : MACOP-B chemotherapy for the treatment of diffuse large-cell lymphoma. Ann Int Medicine 102 : 596 602, 1985.
12）鈴木久三, 有吉 寛, 尾山 淳, 他 : 治療の進 歩一 60 歳以上の癌の化学療法. 老人科診療 1 : 209 214, 1988.

13) Armitagge JO, Weisesnburger $\mathrm{MH}$, Hutchins $\mathrm{M}$, et al : Chemotherapy for diffuse-large cell lymphoma-Rapidly responding patients have more durable remissions. J Clin Oncol $4: 160$ $\sim 164,1986$.

14) Dixon DO, Neilan B, Jones SE, et al : Effect of age on therapeutic outcome in advanced diffuse histiocytic lymphoma: the southwest oncology group experience. J Clin Oncol $4: 295$ $\sim 305,1986$.

15）尾山 淳, 森田晧三, 須知泰山, 他 : 悪性リン 八腫の予後因子. 癌の臨床 $34: 705 \sim 713,1988$.

16）若狭治毅, 毛利昇理, 森茂郎, 他: 新分類に よる悪性リンパ腫アトラス (小島 瑞, 他編). 51 77頁, 文光堂, 東京, 1984 .

17）渡辺 昌：リンパ節生検. リンパ采腫瘍へのア プローチ. 光文堂, 東京, 1985 .

18）鶴田至宏, 宮原 裕, 佐藤武男, 他：頭頸部初 発の non-Hodgkin リンパ腫の病理組織学的検 討. 頭頸部腫場 $14: 344,1987$.

19）新部英男, 玉木義雄, 秋元哲夫 : 悪性リンパ腫 の病理分類と診断法. 癌の臨床 $34: 541 \sim 554$, 1988.

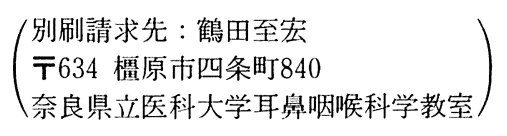

